a teller of stories (not all suited to Victorian drawingrooms), he had a keen sense of humour and an impish wit which made him the best of companions. Wood's "Physical Optics", now in its third edition, and his little satirical book of poems, illustrated by himself, "How to Tell the Birds from the Flowers", have both been best-sellers for many years.

Wood was a great traveller. Sabbatical years seemed to recur at very close intervals, and Wood's visits to Europe became almost an event in the scientific world. He never failed to bring with him something original and ingenious; and, of course, a fund of new stories. Like his great friend, C. V. Boys, Wood was essentially an experimenter who loved to do everything for himself. A craftsman in the laboratory arts and a manipulator of the very highest dexterity, Wood found it difficult to entrust any substantial part of his experimental work to others. When he embarked on an experiment, every. thing was sacrificed to its consummation in the shortest possible time. All apparatus and equipment, regardless of its normal purpose, was ruthlessly sacrificed to the end in view; and it only took some fifteen seconds to smash a perfectly good electric light bulb and extract the leadglass stem if Wood happened to be in a hurry for a bit of sealing-in glass.

Wood was born in Concord, Mass., in 1868, and was educated at Harvard and the University of Berlin. He became professor of experimental physics at Johns Hopkins University in 1901, where he took charge of Rowland's machines for ruling diffraction gratings and initiated the production of blazed echelette gratings for use in the infra-red. His published papers, which exceed 250 in number, cover a wide field and include experimental work in physical optics, on interference and diffraction and a study of the groove form and intensity distribution in gratings. He made extensive observations of the optical properties of the vapour of sodium at low pressure in which he observed the fluorescence and resonance spectra. Similar observations were made with the vapour of iodine. He studied the use of infra-red and ultra-violet photography of terrestrial objects and also their application to a study of the moon. These are only a few examples, chosen almost at random, of the many fields in physical optics in which he worked with such distinction. He was one of the really great experimenters with an almost uncanny flair for choosing the simplest and best method of attack. He seemed always to know what would work.

Wood received many honours, including Rumford Medals given by the American Academy of Arts and Sciences and the Royal Society, the Ives Medal and the Draper Medal of the U.S. National Academy of Science for his contributions to astrophysics. He was a foreign member of the Royal Society and was awarded honorary degrees by many of the leading universities of Europe. In 1892 he married Gertrude Ames, of San Francisco.

T. R. MERTON

\section{Lord Horder, G.C.V.O.}

IN his long life of eighty-four years, which came to an end on August 13, Lord Horder witnessed and participated in a revolutionary change in the science of medicine and in the organization of its service to the public. In any age he would have been successful, for he was endowed with that indefinable gift for recognition of disease, great skill in clinical examination and sympathy with human suffering which characterize the ideal physician. To these talents he added scientific knowledge and experience. Up to the present century the diagnostician's tools were limited to a few simple instruments to assist the otherwise unaided senses in the examination of the heart, lungs, eyes and larynx. Horder, trained as a pathologist, was able to add to the examination of the patient's body the examination of the patient's blood, his cerebrospinal fluid, his secretions and excretions. He was one of the first to bring the laboratory to the bedside, to foster and promote clinical pathology. It is little wonder that he soon became the most sought-after physician of his time.

Horder's early research work is recorded in contributions to the annual reports of the Medical Officer of the Local Government Board. In the report for 1906-7, he published a paper "On a Study of the Micro-organisms associated with Rheumatic Fever and Malignant Endocarditis". In the report for 1907-8 he contributed a paper with $F$. W. Andrewes "On the Behaviour of the Leucocytes in Relation to Infection by and Vaccination against the Pyogenic Cocci", and with M. H. Gordon reported "On an Investigation of Protective Agents in Meningococcus Infections". His chief contribution to clinical medicine was a paper on 150 cases of infective endocarditis in the Quarterly Journal of Medicine of April 1909, in which he stated that with care a positive blood-culture of one or other of three types of streptococci could be obtained in 90 per cent of cases. In 1907 he edited Abel's "Laboratory Handbook of Bacteriology"; he wrote on pleurisy in Allbutt and Rolleston's "System of Medicine" in 1909; and in 1910 he published his "Clinical Pathology in General Practice", in which he included an account of vaccine therapy. He edited the second edition of the "British Encyclopædia of Medical Practice", published in 1950, and in 1953 published "Fifty Years of Medicine", an expanded version of his Harben Lectures delivered at the Royal Institute of Public Health and Hygiene in December 1952, which are partly autobiographical.

Horder served on the Minister of Health's Advisory Committee during 1935-39, and during the Second World War rendered conspicuous service as chairman of a committee appointed to inquire into the health conditions of air-raid shelters, and also as medical adviser to Lord Woolton at the Ministry of Food.

He promoted many good causes. For example, physical medicine, industrial hygiene, eugenics, cremation and noise and smoke abatement owe much to his advocacy. In particular, the combating of two scourges of mankind, rheumatism and cancer, concerned him. He was chairman of the Empire Rheumatism Council from its inception in 1936 until 1953. As chairman of the Scientific Advisory Committee of the British Empire Cancer Campaign he rendered great service, and he largely instituted a clinical review and follow-up of all cancer cases in London hospitals. Only last year he attended an international cancer conference at São Paulo, Brazil.

"Those whom the gods love die young." Lord Horder gave a new interpretation of the aphorism, for up to the day of his death his mental powers were unabated, and he was still young in spirit, in enthusiasm, and in love for mankind and for the profession which he adorned.

Arthur MacNalty 